\title{
Comparative Performance of Selected RSJ Bivoltine Silkworm (Bombyx mori L.) Breeds under Subtropical region of Jammu
}

\author{
Murali S., Tayal M. K., Anil Dhar
}

Regional Sericultural Research Station, Central Silk Board, Miran Sahib, Jammu, India

\begin{abstract}
The study was conducted on selected silkworm breeds viz., RSJ 1, RSJ 3, RSJ 4, RSJ 11, RSJ 13, RSJ 14 and RSJ 15 were utilized. Observations on the different morphological and economic traits of silkworm, Bombyx mori $L$. were taken. The perusal of the data reveals that the fecundity was recorded from 384.00 (RSJ 13) to 493.67 (RSJ 1) and hatching per cent ranged from 86.88 (RSJ 13) to 97.61 (RSJ 3). The larval weight varied in the range of $36.46 \mathrm{~g}$ (RSJ 13) to $42.89 \mathrm{~g}$ (RSJ 11) whereas, larval duration was observed in the range of 24.00 (RSJ 13) days to 25.03 (RSJ 3) days. The larval length recorded as on $6^{\text {th }}$ day $7.68 \mathrm{~cm}$ (RSJ 14) to $8.32 \mathrm{~cm}$ (RSJ 11). Single cocoon weight ranged from $1.24 \mathrm{~g}$ (RSJ 3) to $1.77 \mathrm{~g}$ (RSJ 15). The highest single cocoon weight was RSJ 15 (1.77 g), Single shell weight ranged from $0.22 \mathrm{~g}$ to $0.35 \mathrm{~g}$. Maximum shell weight recorded in RSJ 14 (0.35 g), Shell percentage 16.73 per cent (RSJ 13) to 21.12 per cent (RSJ 3). Maximum yield recoded in $R S J 1$ (16.01 Kg), was observed significantly superior compared to others. These findings will help the sericulturists in finding suitable breed for getting more economic returns from silkworm rearing. It is observed that RSJ 1 is having highest yield per 10, 000 larvae.
\end{abstract}

Keywords - Fecundity, Larval duration, Larval length, Cocoon yield, Shell ratio, Bombyx mori $L$.

\section{INTRODUCTION}

The silkworm, Bombyx mori L. spins valuable silk fibre, making it one of the most beneficial insects to mankind, and is becoming an attractive multifunctional material for both textile and non-textile uses (Murthy et al., 2013).The practice of silk production involves diverse activities from the cultivation of host plants to silk processing, which engage people of all spectrums. Further, the by-products also find uses ranging from fertilizers in rural areas to pharmaceutical industries (Legay, 1958). Thus, silk production has the potential to make a significant contribution to the economy of many countries where there is surplus labor, low-costs of production and a willingness to adopt new technologies (Hajare et al., 2007).

However, rearing of superior silkworm strains that well adapt to the local environment is an important method for enhancing cocoon quality, increasing cocoon yield an improving economic benefit (Nguku et al., 2009). Differences in agro-ecologies across regions including significant distinctions in temperature and humidity require a type of silkworm strain which is both hyper silkgeneous and adversity resistant (Basavaraja et al., 2005). Rearing performance in silkworms is also affected by ecological, biochemical, physiological and quantitative characters, which influence growth and development, quantity and quality of silk they produce in different geographical locations (Virk et al., 2011; Ramesh et al., 2012; Anandakumar and Michael, 2012 and Reddy et al., 2012). The success in silkworm rearing depends on the various factors including successful implementation of technological and managerial tools along with high yielding and best-suited mulberry varieties and silkworm strains (Rajan and Himantharaj, 2005). In addition, the B. mori insect is an oligophagous herbivore and depends mainly on the quality of mulberry leaves and environmental conditions for its development (Murthy et al., 2007).

\section{METHODOLOGY}

The experiment was carried out on seven B. mori parental RSJ breeds viz., RSJ 1, RSJ 3, RSJ 4, RSJ 11, RSJ 13, RSJ 14 and RSJ 15 maintained at the RSRS, Jammu during spring, 2016 and were incubated for 9-12 days in a neat and clean, disinfected room at $80-85 \%$ Humidity and $24-25^{\circ} \mathrm{C}$ Temperature with 18 hrs light till pin head stage, at this stage black - boxing was done to ensure maximum hatching on exposure to bright light. The hatched larvae were reared separately under uniform laboratory conditions as described by Yokoyama (1963) and Krishnaswami (1978). During the entire period of research, same micro-climate and feeding conditions were ensured as per the larval stage. The 
experiment analysed for morphological charateristics of egg, larvae and cocoon parameters (Table 1) and biological studies of larvae includes feeding duration (Table 2), hatching percentage, larval weight (Table 5) and total larval duration of different instars were studied, which reflects their variation among the breeds (Table 3) and cocoon characteristics of all breeds were recorded.

All the breeds were reared in three replications by following standard rearing techniques (Krishnaswami, 1978). Three hundred larvae were retained after $2^{\text {nd }}$ moult in each replication. The data pertaining to the morphology/ phenotypic and biological/economic parameters were recorded. During the entire period of research, same microclimate and feeding conditions were ensured as per the larval stage.

At egg stage: Egg shape, egg colour, hatching percentage and average fecundity per female moth were studied.

At larval stage: Larval colour, markings, larval length and mean weight of 10 larvae on each day of $\mathrm{V}$ instar were studied and analyzed for different races.

The statistical analysis was done with the help of software SPSS and weight of larvae was measured with electronic balance.

At cocoon stage: cocoon shape, cocoon colour, cocoon grain and economic characters of cocoon were noted.

\section{RESULTS AND DISCUSSION}

\subsection{Morphological Qualitative Parameters:}

Egg: All the RSJ breeds which are selected are ellipsoidal in shape, grey in color and shell color was recorded as white (Table 1). Similar results were obtained by Anita et al. (2014).

Larvae: Color of newly hatched larvae was recorded as black and haemolymph color was transparent in all the breeds. The pattern of larvae was observed marked in RSJ 1, RSJ 3, RSJ 11, RSJ 14, RSJ 15 and RSJ 4, RSJ 13 was recorded as plain (Table 1). The results were agreement with work done by Anita et al. (2014).

Cocoon: All the RSJ breeds were distinctly white in color. The shape of cocoon was dumbbell and constricted (DC) in RSJ 1, RSJ 11 and RSJ 15 and oval in RSJ 3, RSJ 4, RSJ 13 and RSJ 14 respectively. The build and grain of among all the breeds was recorded hard (RSJ 1, RSJ 11, RSJ 14, RSJ 15), thin (RSJ 3. RSJ 4, RSJ 13) and medium respectively (Table 1). Similar results were obtained by Anita et al. (2014).

\subsection{Larval biological parameters:}

\subsubsection{Feeding duration:}

First instar: The active period of feeding among all the breeds was recorded three days five hours (Table 2).
Second instar: Two days fourteen hours were recorded as most active period of feeding among all the breeds (Table 2).

Third instar: The active feeding period was recorded among all breeds was three days sixteen hours (Table 2).

Fourth instar: The feeding period was observed among all breeds varying between 4.04 to $4.13 \mathrm{~h}$ observed in RSJ 1 and RSJ 15 respectively (Table 2).

Fifth instar: There is variation among breeds was recorded, eight days one hour more active feeding period was recorded in RSJ 4 and less i.e. six days observed in RSJ 13 respectively (Table 2).

The total average feeding duration among all the breeds was more in RSJ 11 i.e. twenty two days nine hours and less was recorded in RSJ 13 i.e. nineteen days fifteen hours respectively (Table 2).

\subsubsection{Larval duration:}

First instar: The period among all the breeds was recorded as four days five hours respectively (Table 3 ).

Second instar: Three days fourteen hours were recorded as $2^{\text {nd }}$ stage larval period among all the breeds (Table 3 ).

Third instar: Four days sixteen hours were recorded as $3^{\text {rd }}$ stage larval period among all the breeds (Table 3).

Fourth instar: The larval period was observed five days thirteen hours among all the breeds except RSJ 1 five days eight hours (Table 3).

Fifth instar: There is variation among breeds was recorded, more days recorded, seven days three hours in RSJ 3 and less i.e. six days observed in RSJ 13 respectively (Table 3).

The total average larval duration among all the breeds was more in RSJ 3 i.e. Twenty five days three hours and less was recorded in RSJ 13 i.e. twenty four days respectively (Table 5) and larval period was ranged from $25.03-24.00$ days. The results were agreement with Krishnaswami (1978) reported that the larval duration was longer in race M-5 (24.17), but it was non agreement with results reported by Bothikar et al. (2014) the larvae reared on S -1635 recorded 19.66 days. Under ideal conditions it has been reported that the total larval duration is 25-30 days for selected JAM breeds (Raina, 2000). The results were justified with work done by Anita et al. (2014) reported similar results on JAM breeds, the larval duration which ranges between 23.22 - 26.16 days.

\subsubsection{Larval length:}

The length of $5^{\text {th }}$ instar larvae was recorded from first day to sixth day results revealed that there is significant differences were observed among all the breeds except in first day (Table 4). During first day the larval length ranges from 4.20 (RSJ 13) to $4.28 \mathrm{~cm}$ (RSJ 4), $2^{\text {nd }}$ day it was ranges from $4.60 \mathrm{~cm}$ (RSJ 4) to $5.58 \mathrm{~cm}$ (RSJ 14), $3^{\text {rd }}$ day 
ranges between 6.06 (RSJ 4) to $6.86 \mathrm{~cm}$ (RSJ 13), $4^{\text {th }}$ day recorded as $7.02 \mathrm{~cm}$ (RSJ 15) to $7.56 \mathrm{~cm}$ (RSJ 13), $5^{\text {th }}$ day it was ranges from 7.22 (RSJ 14) to $7.84 \mathrm{~cm}(\mathrm{RSJ} 1)$ and $6^{\text {th }}$ day recorded as $7.68 \mathrm{~cm}$ (RSJ 14) to $8.32 \mathrm{~cm}$ (RSJ 11) (Table 4). Similar results were recorded by 6.71 to $7.25 \mathrm{~cm}$ (Prabu et al., 2011) and 6.12 to $7.05 \mathrm{~cm}$ (Balasundaram et al., 2013). The data shows that there is increase in larval length from day 1 to day 6 of 5th instar. The length of silk worm depends on amount of food it consumes. Length of larvae increases until larvae reaches it's spinning state $\left(6^{\text {th }}\right.$ day). When it reaches spinning stage the larvae reduce in size to one third of its normal length, it is the characteristic feature of a silk worm. This reduction in size increases pressure on silk glands to eject silk from the glands. Hence there is a sudden decrease in length on $6^{\text {th }}$ day onwards. This decrease in length continues until pupal stage. The results also agreement with work done by Venugopal Reddy et al. (2015) revealed that the larval length varies from 5.00 to $7.43 \mathrm{~cm}$.

\section{ECONOMIC PARAMETERS}

The data pertaining to nine economic traits viz., hatching \%, larval duration $(\mathrm{h})$, larval weight $(\mathrm{g})$, cocoon yield per 10,000 larvae by number, cocoon yield per 10,000 larvae by weight, pupation rate, cocoon weight, cocoon shell weight, and cocoon shell ratio of five breeds were presented in Table 5. The perusal of the data reveals that the fecundity was recorded from 384.00 (RSJ 13) to 493.67 (RSJ 1) which shows statistically non significant among all the breeds and hatching per cent ranged from 86.88 (RSJ 13) to 97.61 (RSJ 3) and showing statistically significant among all the breeds where as larval duration shows statistically significant among all the breeds and recorded to a maximum duration of 25.03 days (RSJ 3) and minimum of 24.00 days (RSJ 13) where as larval weight was recorded to a maximum of $42.89 \mathrm{~g}$ (RSJ 11) and minimum of $36.46 \mathrm{~g}$ (RSJ 13) showing statistically significant among all the breeds. The pupal weight recorded more weight in RSJ 1 and less weight was observed in RSJ 14 having $13.56 \mathrm{~g}$ and $11.36 \mathrm{~g}$ respectively, whereas pupation rate showing statistically non significant among all the breeds and it was recorded as highest 86.67 per cent (RSJ 1, RSJ 3) and less 82.40 per cent (RSJ 4). With regard to yield per 10,000 larvae by number was recorded the highest (9440.00) in RSJ 1 and lowest in RSJ 4 (8746.67). Yield per 10,000 larvae by weight $(\mathrm{kg})$, ranged to the maximum of $16.01 \mathrm{~kg}$ in RSJ 1 and minimum of $9.60 \mathrm{~kg}$ in RSJ 4 showing statistically significant among all the breeds with regard both by number and weight basis. The weight of cocoon found to the highest of $16.95 \mathrm{~g}$ in RSJ 1 and lowest of 15.18 $\mathrm{g}$ in RSJ 14 shows statistically non significant among all the breeds. The cocoon weight ranged from the maximum of $1.77 \mathrm{~g}$ (RSJ 15) and minimum of $1.24 \mathrm{~g}$ (RSJ 3). The shell weight was maximum $(0.35 \mathrm{~g})$ in RSJ 14 and minimum in RSJ 4 (0.22 g) shows statistically significant among all the breeds with respect to both cocoon weight and shell weight. The shell ratio (\%) shows statistically significant among all the breeds and was highest in RSJ 3 (21.12) and lowest in RSJ 13 (16.73) respectively.

The highest average fecundity per moth was 522 in Jam 2 and lowest was 355 in Jam 18 reported by Anita et al. (2014) these results were non agreement with our results. The lowest hatching percent $(93.79 \%)$ was obtained in Jam 11 race and the highest $(94.17 \%)$ was obtained in Jam 27 race, with a mean of 93.92 per cent in all studied races Anita et al. (2014). It was justified with our results, 86.88 (RSJ 13) to 97.61 (RSJ 3).

The larval weight was agreement with results reported by Bothikar et al. (2014) i.e. $40.54 \mathrm{~g}$ which were reared on S 1635 and other breeds which on par with silkworm reared on variety $M$ - 5 and breeds having larval weight ranges between $36.46 \mathrm{~g}$ (RSJ 13) to $42.89 \mathrm{~g}$ (RSJ 11). Similar results were recorded by Pakhale et al. (2014), the larval weight was ranges from 33.77-40.67 g.

The larval duration was non agreement with results reported by Pakhale et al. (2014), the larval duration ranges from 21.04 - 22.28 days, our results shows that 24.00-25.03 days among the breeds.

The single cocoon weight was not justified with results reported by Bothikar et al. (2014) i.e., $1.86 \mathrm{~g}$ which were reared on S - 1635 and Rayer (2006) and Chakravorty (2004) reported the highest single cocoon weight on variety V- 1 and also justified with results reported by Pakhale et al. (2014) single cocoon weight ranges from 1.76-1.86 g, our results revealed that it ranges between 1.24-1.77 $\mathrm{g}$.

The single shell weight was non agreement with Bothikar et al. (2014) report the silkworms which reared on S-1635 but it was similar results with variety $M$ - 5 reported by Bothikar et al. (2014). Rayer (2006) and Chakravorty (2004) reported the highest single shell weight on variety V- 1 and also not justified with results reported by by Pakhale et al. (2014) single cocoon weight ranges from 0.32 $-0.36 \mathrm{~g}$, our results revealed that it ranges between 0.22 (RSJ 4) - $0.35 \mathrm{~g}$ (RSJ 14).

The cocoon shell percentage varies between 17.84 to 19.93 per cent reported by Bothikar et al. (2014) and it was agreement with our results the shell percentage varies between 16.73 (RSJ 13) - 21.12 per cent (RSJ 3). Similar results Rayer (2006) and Chakravorty (2004) reported the cocoon shell percentage. 
Cocoon yield per 10,000 larvae brushed varied in the range of $18.66 \mathrm{Kg}$ to $16.59 \mathrm{Kg}$ reported by Bothikar et al. (2014) and it was non agreement with our results on $\mathrm{S}-1635$ but similar results which reared on variety $\mathrm{M}-5$, the yield varies between $9.97-15.95 \mathrm{Kg}$.

Varietal differences for studied traits in B. mori has been reported by Ahsan et al., 2000, Li et al., 2001; Furdui et al., 2010. Similar studies on varietal diversity have also been sustained by the findings of Reza et al.,1993, Mistri and Jayaswal, 1992; Ahsan et al., 1999; Umashankara and Subramanya, 2002; Nezhad et al., 2009; Nguku et al., 2007; Nguku et al., 2009; Zannata et al., 2009; Pal and Moorthy, 2011).

\section{CONCLUSION}

The obtained data showed that there are highly significant differences among the breeds for all the studied characters. There is a high positive correlation between economic parameters among all the breeds studied. The differences in obtained results are due to the variability and genotype characters for each individual of every breed.

\section{ACKNOWLEDGEMENTS}

The authors wish to thank the authorities of Regional Sericultural Research Station, CSB, Miran Sahib, Jammu 181101, J \& K, India for their encouragement to undertake this work. The authors are also thankful to Dr. Anil Dhar, Scientist-D, for his assistance in conducting effective work and close monitoring during the study. We acknowledge all technical staff who assisted their help in rearing.

\section{REFERENCES}

[1] Ahsan M K, Rahman S M and Ali I A. 1999. Inheritance of some quantitative traits in fifteen indigenous varieties of silkworm, Bombyx mori L. Univ. J. Zool. Rajshahi Univ. 18: 79-83.

[2] Ahsan M K, Rahman S M and Ali I A. 2000. Variability of some quantitative traits in the hybrids of silkworm, Bombyx mori L. Univ. J. Zool. Rajshahi Univ. 19: 20-24.

[3] Anandakumar M D and Michael A S. 2012. Effect of nutritive additive of mulberry and its impact on nutritional components of silkworm, Bombyx mori L. Int. J. Adv. Biotech. Res. 3:523-529.

[4] Anita, Tripathi N K, Bhatti A A and Poonam, 2014. Comparative analysis of developmental stages in six different bivoltine races of Bombyx mori. International Journal of Recent Scientific Research, 5(11): 19691972.
[5] Balasundaram

$\mathrm{D}$,

Ganesh

Prabu P, Selvisabhanayakam, Mathivanan, V and Ramesh V. 2013. Studies on the nutritional supplementation of vitamin $\mathrm{C}$ treated $\mathrm{MR}_{2}$ mulberry leaves fed by $\mathrm{V}$ instar larvae of silkworm, Bombyx mori (L.) (Lepidoptera: Bombycidae) in relation to feed efficacy and growth rate. International Journal of Research in Biotechnology and Biochemistry, 3(1): 11-18.

[6] Basavaraja H K, Aswath S K, Kumar N S, Reddy N M and Kalpana G V. 2005. Silkworm Breeding and Genetics. Central Silk Board, Bangalore.

[7] Bothikar P A, Jadhav S S and Shinde Y A. 2014. Growth and development of silk worm (Bombyx mori L.) on mulberry leaves. Jr. of Industrial Pollution Control, 30(2): 239-241.

[8] Chakravorty, N J. 2004. Studies on different parameters of B. mori. Seridoc, 20(2): 21-23.

[9] Furdui E M, Marghitas L A, Dezmirean D, Mihai C M, Bobis O and Pasca I. 2010. Comparative study of biological characters of larvae, crude and dried cocoon in 7 races of Silkworm Bombyx mori L. raised in Transylvania area. Scientific Papers: Animal Science and Biotechnologies, 43(1): 490-493.

[10] Hajare T N, Jadhav A D, Venugopalan M, Patil N G, Chaturvedi A and Maji A K. 2007. Evaluation of sericulture for augmenting agricultural income of marginal farmers in semi-arid region of India. Proceedings of the International Conference on Sericulture Challenges in the $21^{\text {st }}$ Century and the $3^{\text {rd }}$ BACSA Meeting, September 18-21, 2007. Vratza, Bulgaria.

[11] Krishnaswami S. 1978. New technology of silkworm rearing. Bulletin of the Central Sericulture Research and Training Institute, Mysore, pp. 1-10.

[12]Legay J M. 1958. Recent Advances in Silkworm Nutrition. Ann. Rev. Entomol. 3:75-86.

[13]Li M, Yao W, Hou Q, Lin C Q, Chen K P. 2001. Studies of some special characters in the silkworm (Bombyx mori L.) germplasm in China. Sericologia, 41: 527-535.

[14] Mistri P K and Jayaswal K P. 1992. Studies on phenotypic correlations between some economic traits of silkworm, Bombyx mori L. Bull. Seric. Res. 3: 2629.

[15] Murthy V N Y, Ramesh H L, Lokesh G, Munirajappa and Yadav, B R D. 2013. Assessment of six mulberry (Morus) germplasm varieties through moulting and bioassay parameters by using Crossbreed Silkworms Bombyx mori L. for Commercial Exploitation in Kolar 
District, Karnataka, India. Int. Res. J. Biol. Sci., 2: 6975.

[16] Nezhad M S, Mirhosseini S Z, Gharahveysi S, Mavvajpour M and Seidavi A R. 2009. Analysis of Genetic Divergence for classification of morphological and larval gain characteristics of peanut cocoon silkworm (Bombyx mori L.) Germplasm. American-Eurasian J. Agric. \& Environ. Sci. 6(5): 600-608.

[17] Nguku E K, Adolkar V V, Raina S K, Mburugu K G, Mugenda O M and Kimbu D M. 2009. Performance of six Bivoltine Bombyx mori. (Lepidoptera: Bombyxidae) silkworm strains in Kenya. The Open Entomology Journal, 3: 1-6.

[18] Nguku E K, Muli E M and Raina S K. 2007. Larvae, cocoon and post-cocoon Characteristics of Bombyx mori L. (Lepidoptera:bombyxidae) fed on mulberry leaves fortified with Kenyan royal jelly. J. Appl. Sci. Environ. Manage. 11(4): 85-89.

[19] Pal N B and Moorthy S M. 2011. Assessment of variability in larval and cocoon traits in some genotypes of bivoltine silkworm, Bombyx mori L. International Journal of Research in Biological Sciences, 1(4): 59-65.

[20] Pakhale S G, Bothikar P A, Lande U L, Shendage S A. 2014. Evaluation of Some Mulberry Varieties for Rearing Performance and Economic Traits of Silkworm (Bombyx mori L.). Journal of Environmental Science, Toxicology and Food Technology (IOSR-JESTFT) 8: 63-65.

[21] Prabu P G, Sabhanayakam S, Mathivanan V and Balasundaram D. 2011. Studies on the Growth Rate of Silkworm, Bombyx mori (L.) (Lepidoptera: Bombycidae) Fed with Control and Silver Nanoparticles (AgNps) Treated MR2 Mulberry Leaves. Int. J. Indust. Entomol. 22(2): 39-44.

[22] Rajan R K. and Himantharaj M T. 2005. Silkworm Rearing Technology. Central Silk Board, Bangalore.
[23] Ramesha C, Lakshmi H, Kumari S S, Anuradha C M and Kumar C S. 2012. Nutrigenetic screening strains of the mulberry silkworm, Bombyx mori, for nutritional efficiency. J. Ins. Sci. 12:1-18.

[24] Rayer S G., 2006. Stability of improved mulberry varities to shootlet feeding and it's impact on cocoon production. J. Maharashtra agric. Univ. 32(3) : 367369.

[25] Reddy N M, Kumar S N, Naseema Begum A R, Moorthy S M and Qadri S M H. 2012. Performance of bivoltine silkworm hybrids of Bombyx mori L. involving parental foundation crosses of different generation. Int. J. Res. Zool. 2: 1-5.

[26] Reza A M S, Rahman M S and Rahman S M. 1993. Studies on the variation of some larval traits in different breeds of silkworm, Bombyx mori L. Univ. J. Zool. Rajshahi Univ. 12: 21-24.

[27] Umashankara M L and Subramanya G. 2002. Correlation between larval weight and cocoon characters in five breeds of silkworm, Bombyx mori L. Geobios, 29: 154-157.

[28] Venugopal Reddy B, Divya P, Anitha M. 2015. Quantitative profile Analysis of Mulberry Silkworm, Bombyx mori. L. (CSR $2 \times$ CSR 4). International Letters of Natural Science, 34: 34-41.

[29] Virk J S, Kaur L and Singh B. 2011. Evaluation of different strains of mulberry silkworm and eri silkworm for the development of sericulture in Punjab. Int. J. agric. Sci. 7: 266-269.

[30] Yokayama, 1963. Sericulture Annual Review. Entomology, pp. 287-298.

[31] Zanatta D B, Bravo J P, Barbosa J F, Munhoz R E F and Fernandez M A. 2009. Evaluation of economically important traits from sixteen parental strains of the silkworm, Bombyx mori L. (Lepidoptera: Bombyxidae). Neotropical Entomology, 38(3): 327331.

Table.1: Morphological qualitative characteristics of egg, larvae and cocoon parameters of RSJ breeds

\begin{tabular}{|c|c|c|c|c|c|c|c|c|c|c|}
\hline \multirow[b]{2}{*}{ Breeds } & \multicolumn{3}{|c|}{ Egg } & \multicolumn{3}{|c|}{ Larvae } & \multicolumn{3}{|c|}{ Cocoon } & \multirow[b]{2}{*}{ Grains } \\
\hline & Shape & $\begin{array}{c}\text { Shell } \\
\text { Colour }\end{array}$ & $\begin{array}{l}\text { Egg } \\
\text { colour }\end{array}$ & $\begin{array}{c}\text { Colour of } \\
\text { Newly } \\
\text { Hatched }\end{array}$ & $\begin{array}{c}\text { Haemoly- } \\
\text { mph } \\
\text { Colour }\end{array}$ & $\begin{array}{l}\text { Larval } \\
\text { pattern }\end{array}$ & Colour & Shape & Build & \\
\hline RSJ - 1 & $E$ & $\mathrm{~W}$ & G & B & $\mathrm{T}$ & $\mathrm{M}$ & $\mathrm{W}$ & $\mathrm{DC}$ & $\mathrm{H}$ & $\mathrm{M}$ \\
\hline RSJ - 3 & $\mathrm{E}$ & $\mathrm{W}$ & $\mathrm{G}$ & B & $\mathrm{T}$ & $\mathrm{M}$ & $\mathrm{W}$ & $\mathrm{O}$ & $\mathrm{T}$ & $\mathrm{M}$ \\
\hline RSJ - 4 & $\mathrm{E}$ & $\mathrm{W}$ & G & B & $\mathrm{T}$ & $\mathrm{P}$ & $\mathrm{W}$ & $\mathrm{O}$ & $\mathrm{T}$ & $\mathrm{M}$ \\
\hline RSJ - 11 & $\mathrm{E}$ & $\mathrm{W}$ & G & B & $\mathrm{T}$ & $\mathrm{M}$ & $\mathrm{W}$ & $\mathrm{DC}$ & $\mathrm{H}$ & $\mathrm{M}$ \\
\hline
\end{tabular}




\begin{tabular}{|c|c|c|c|c|c|c|c|c|c|c|}
\hline RSJ - 13 & E & W & G & B & T & P & W & O & T & M \\
\hline RSJ - 14 & E & W & G & B & T & M & W & O & H & M \\
\hline RSJ - 15 & E & W & G & B & T & M & W & DC & H & M \\
\hline
\end{tabular}

Note: E - Ellipsoid, W-White, Y - Yellow, G- Grey, SS - Sand Stone, B-Black, T- Transparent, O -Oval, M- Medium, DC Dumbell Constricted, H-Hard, T- Thin, P-Plain, M-Marked

Table.2: Data showing feeding duration among different stages of RSJ breeds during spring rearing (2016)

\begin{tabular}{|c|c|c|c|c|c|c|}
\hline \multirow{2}{*}{ Race/Breed } & \multicolumn{5}{|c|}{ Different stages (Days: h) } & \multirow{2}{*}{$\begin{array}{c}\text { Total Avg. } \\
\text { duration } \\
\text { (Days: h) }\end{array}$} \\
\hline & $1^{\text {st }}$ instar & $2^{\text {nd }}$ instar & $3^{\text {rd }}$ instar & $4^{\text {th }}$ instar & $5^{\text {th }}$ instar & \\
\hline RSJ -1 & $3.05 \pm 0.00$ & $2.14 \pm 0.00$ & $3.16 \pm 0.00$ & $4.04 \pm 0.04$ & $6.01 \pm 0.02$ & $20.14 \pm 1.72$ \\
\hline RSJ -3 & $3.05 \pm 0.00$ & $2.14 \pm 0.00$ & $3.16 \pm 0.00$ & $4.08 \pm 0.00$ & $7.03 \pm 0.02$ & $20.18 \pm 0.02$ \\
\hline RSJ -4 & $3.05 \pm 0.00$ & $2.14 \pm 0.00$ & $3.16 \pm 0.00$ & $4.10 \pm 0.03$ & $8.01 \pm 0.44$ & $21.19 \pm 0.50$ \\
\hline RSJ -11 & $3.05 \pm 0.00$ & $2.14 \pm 0.00$ & $3.16 \pm 0.00$ & $4.11 \pm 0.03$ & $6.10 \pm 0.12$ & $22.09 \pm 0.56$ \\
\hline RSJ -13 & $3.05 \pm 0.00$ & $2.14 \pm 0.00$ & $3.16 \pm 0.00$ & $4.08 \pm 0.00$ & $6.00 \pm 0.00$ & $19.15 \pm 0.00$ \\
\hline RSJ -14 & $3.05 \pm 0.00$ & $2.14 \pm 0.00$ & $3.16 \pm 0.00$ & $4.10 \pm 0.03$ & $7.10 \pm 0.57$ & $22.06 \pm 1.06$ \\
\hline RSJ -15 & $3.05 \pm 0.00$ & $2.14 \pm 0.00$ & $3.16 \pm 0.00$ & $4.13 \pm 0.00$ & $7.01 \pm 0.02$ & $21.01 \pm 0.02$ \\
\hline
\end{tabular}

Table.3: Data showing larval duration among different stages of RSJ breeds during spring rearing (2016)

\begin{tabular}{|c|c|c|c|c|c|c|}
\hline \multirow{2}{*}{ Races/breeds } & \multicolumn{5}{|c|}{ Different stages (Days : h) } & \multirow{2}{*}{$\begin{array}{c}\text { Total } \\
\text { duration } \\
\text { (Days : h) }\end{array}$} \\
\hline & $1^{\text {st }}$ instar & $2^{\text {nd }}$ instar & $3^{\text {rd }}$ instar & $4^{\text {th }}$ instar & $5^{\text {th }}$ instar & \\
\hline RSJ -1 & $4.05 \pm 0.00$ & $3.14 \pm 0.00$ & $4.72 \pm 0.48$ & $5.08 \pm 0.05$ & $6.01 \pm 0.02$ & $24.01 \pm 0.02$ \\
\hline RSJ -3 & $4.05 \pm 0.00$ & $3.14 \pm 0.00$ & $4.16 \pm 0.00$ & $5.13 \pm 0.00$ & $7.03 \pm 0.02$ & $25.03 \pm 0.02$ \\
\hline RSJ -4 & $4.05 \pm 0.00$ & $3.14 \pm 0.00$ & $4.16 \pm 0.00$ & $5.13 \pm 0.00$ & $6.49 \pm 0.44$ & $24.49 \pm 0.44$ \\
\hline RSJ -11 & $4.05 \pm 0.00$ & $3.14 \pm 0.00$ & $4.16 \pm 0.00$ & $5.13 \pm 0.00$ & $6.10 \pm 0.12$ & $24.10 \pm 0.12$ \\
\hline RSJ -13 & $4.05 \pm 0.00$ & $3.14 \pm 0.00$ & $4.16 \pm 0.00$ & $5.13 \pm 0.00$ & $6.00 \pm 0.00$ & $24.00 \pm 0.00$ \\
\hline RSJ -14 & $4.05 \pm 0.00$ & $3.14 \pm 0.00$ & $4.16 \pm 0.00$ & $5.13 \pm 0.00$ & $6.34 \pm 0.57$ & $24.34 \pm 0.57$ \\
\hline RSJ -15 & $4.05 \pm 0.00$ & $3.14 \pm 0.00$ & $4.16 \pm 0.00$ & $5.13 \pm 0.00$ & $7.01 \pm 0.02$ & $25.01 \pm 0.02$ \\
\hline
\end{tabular}

Table.4: Showing length of fifth instar larvae of RSJ breeds during spring (2016)

\begin{tabular}{|c|c|c|c|c|c|c|}
\hline \multirow{2}{*}{ Breeds } & \multicolumn{5}{|c|}{ Days ( $5^{\text {th }}$ instar $)$} & \multirow[b]{2}{*}{6} \\
\hline & 1 & 2 & 3 & 4 & 5 & \\
\hline RSJ -1 & $4.24 \pm 0.11$ & $5.10 \pm 0.27$ & $6.82 \pm 0.19$ & $7.06 \pm 0.21$ & $7.84 \pm 0.17$ & $8.28 \pm 0.15$ \\
\hline RSJ -3 & $4.26 \pm 0.11$ & $5.56 \pm 0.43$ & $6.32 \pm 0.22$ & $7.48 \pm 0.16$ & $7.42 \pm 0.08$ & $8.02 \pm 0.22$ \\
\hline RSJ -4 & $4.28 \pm 0.15$ & $4.60 \pm 0.34$ & $6.06 \pm 0.21$ & $7.06 \pm 0.21$ & $7.44 \pm 0.11$ & $7.96 \pm 0.13$ \\
\hline RSJ -11 & $4.24 \pm 0.11$ & $5.00 \pm 0.32$ & $6.84 \pm 0.15$ & $7.32 \pm 0.08$ & $7.76 \pm 0.11$ & $8.32 \pm 0.13$ \\
\hline RSJ -13 & $4.20 \pm 0.10$ & $5.18 \pm 0.08$ & $6.86 \pm 0.15$ & $7.56 \pm 0.11$ & $7.48 \pm 0.08$ & $7.90 \pm 0.12$ \\
\hline RSJ -14 & $4.24 \pm 0.11$ & $5.58 \pm 0.13$ & $6.32 \pm 0.19$ & $7.34 \pm 0.15$ & $7.22 \pm 0.13$ & $7.68 \pm 0.08$ \\
\hline RSJ -15 & $4.24 \pm 0.11$ & $5.20 \pm 0.10$ & $6.36 \pm 0.11$ & $7.02 \pm 0.16$ & $7.34 \pm 0.18$ & $7.74 \pm 0.11$ \\
\hline C.D. @ 1\% & - & 0.35 & 0.23 & 0.21 & 0.16 & 0.18 \\
\hline SE. $\mathbf{m} \pm$ & 0.05 & 0.12 & 0.08 & 0.07 & 0.05 & 0.06 \\
\hline C.V. (\%) & 2.77 & 5.20 & 2.74 & 2.22 & 1.73 & 1.76 \\
\hline
\end{tabular}


Table.5: Economic parameters of RSJ breeds reared during spring (2016)

\begin{tabular}{|c|c|c|c|c|c|c|c|c|c|c|c|c|}
\hline \multirow{2}{*}{ Breeds } & \multirow{2}{*}{$\begin{array}{l}\text { Fecundity } \\
\text { by No. }\end{array}$} & \multirow{2}{*}{$\begin{array}{l}\text { Hatching } \\
(\%)\end{array}$} & \multirow{2}{*}{$\begin{array}{l}\text { Larval } \\
\text { duration } \\
\text { (Days : } \\
\text { h) }\end{array}$} & \multirow{2}{*}{$\begin{array}{l}\text { Larval } \\
\text { weight } \\
\text { (g) }\end{array}$} & \multirow{2}{*}{$\begin{array}{l}\text { Pupal } \\
\text { weight } \\
\text { (g) }\end{array}$} & \multirow{2}{*}{$\begin{array}{l}\text { Pupation } \\
\text { rate }(\%)\end{array}$} & \multicolumn{2}{|c|}{ Yield/ 10000 Larvae } & \multirow{2}{*}{$\begin{array}{l}\text { Weight } \\
\text { of } \\
\text { cocoon } \\
(\mathrm{g})\end{array}$} & \multirow{2}{*}{$\begin{array}{l}\text { Single } \\
\text { cocoon } \\
\text { weight } \\
\text { (g) }\end{array}$} & \multirow{2}{*}{$\begin{array}{l}\text { Single } \\
\text { shell } \\
\text { weight } \\
\text { (g) }\end{array}$} & \multirow{2}{*}{$\begin{array}{l}\text { Shell ratio } \\
(\%)\end{array}$} \\
\hline & & & & & & & No. & $\begin{array}{l}\text { Wt. } \\
\text { (Kg) }\end{array}$ & & & & \\
\hline RSJ 1 & $\begin{array}{l}493.67 \\
(22.14)\end{array}$ & $96.54(79.27)$ & 24.01 & 40.33 & 13.56 & $\begin{array}{l}86.67 \\
(68.63)\end{array}$ & $9440.00(97.15)$ & 16.01 & 16.95 & 1.70 & 0.34 & $19.94(26.50)$ \\
\hline RSJ 3 & $\begin{array}{l}418.33 \\
(20.47)\end{array}$ & $97.61(81.08)$ & 25.03 & 42.09 & 13.37 & $\begin{array}{l}86.67 \\
(68.64)\end{array}$ & $9120.00(95.50)$ & 13.44 & 16.23 & 1.24 & 0.26 & $21.12(27.33)$ \\
\hline RSJ 4 & $\begin{array}{l}407.00 \\
(20.17)\end{array}$ & $91.47(73.15)$ & 24.49 & 41.65 & 12.16 & $\begin{array}{l}82.40 \\
(65.20)\end{array}$ & $8746.67(93.52)$ & 9.60 & 16.07 & 1.27 & 0.22 & $17.36(24.60)$ \\
\hline $\begin{array}{l}\text { RSJ } \\
11\end{array}$ & $\begin{array}{l}458.33 \\
(21.42)\end{array}$ & $92.34(74.19)$ & 24.10 & 42.89 & 11.60 & $\begin{array}{l}85.47 \\
(67.62)\end{array}$ & 9373.33(96.81) & 12.40 & 16.06 & 1.25 & 0.23 & $18.66(25.57)$ \\
\hline $\begin{array}{l}\text { RSJ } \\
13\end{array}$ & $\begin{array}{l}384.00 \\
(19.61)\end{array}$ & $86.88(68.92)$ & 24.00 & 36.46 & 12.81 & $\begin{array}{l}82.93 \\
(65.59)\end{array}$ & $9106.67(95.43)$ & 10.37 & 16.14 & 1.72 & 0.29 & $16.73(24.10)$ \\
\hline $\begin{array}{l}\text { RSJ } \\
14\end{array}$ & $\begin{array}{l}485.33 \\
(22.03)\end{array}$ & $92.67(74.67)$ & 24.34 & 37.96 & 11.36 & $\begin{array}{l}86.13 \\
(68.12)\end{array}$ & $9346.67(96.68)$ & 14.27 & 15.18 & 1.65 & 0.35 & $21.09(27.32)$ \\
\hline $\begin{array}{l}\text { RSJ } \\
15\end{array}$ & $\begin{array}{l}402.00 \\
(20.07)\end{array}$ & $92.04(74.40)$ & 25.01 & 41.37 & 12.76 & $\begin{array}{l}84.67 \\
(66.95)\end{array}$ & $9100.00(95.39)$ & 10.28 & 15.48 & 1.77 & 0.30 & $16.84(24.20)$ \\
\hline $\begin{array}{l}\text { C.D. } \\
\text { @ } 1 \%\end{array}$ & - & 6.88 & 0.48 & 2.44 & 1.11 & - & 1.88 & 1.93 & - & 0.17 & 0.02 & 1.83 \\
\hline $\begin{array}{l}\text { SE. } \\
\mathrm{m} \pm\end{array}$ & 0.70 & 2.24 & 0.16 & 0.79 & 0.36 & 1.17 & 0.61 & 0.63 & 0.49 & 0.05 & 0.007 & 0.59 \\
\hline $\begin{array}{l}\text { C.V. } \\
(\%)\end{array}$ & 5.86 & 5.18 & 1.13 & 3.42 & 5.03 & 3.02 & 1.11 & 8.85 & 5.38 & 6.43 & 4.45 & 4.04 \\
\hline
\end{tabular}

